Tropical Journal of Pharmaceutical Research April 2020; 19 (4): 823-828

ISSN: $1596-5996$ (print); 1596-9827 (electronic)

(C) Pharmacotherapy Group, Faculty of Pharmacy, University of Benin, Benin City, 300001 Nigeria.

Available online at http://www.tjpr.org

Original Research Article

http://dx.doi.org/10.4314/tjpr.v19i4.21

\title{
Effect of Evodia rutaecarpa (Juss) Benth extract on Alzheimer disease in mice
}

\author{
Ang Cai', Liu Xiao², Yan-Ping Zhou ${ }^{3}$, Zhi-Guo Zhang ${ }^{4}$, Quan-Wei Yang ${ }^{2 *}$ \\ ${ }^{1}$ Department of Pharmacy, Wuhan Hospital of Traditional Chinese Medicine, Wuhan 430014, ${ }^{2}$ Department of pharmacy, Wuhan \\ No. 1 Hospital, Wuhan 430022, ${ }^{3}$ Traditional Chinese Medicine Clinical College, Hubei University of Chinese Medicine, Wuhan \\ 430065, " Department of Pharmacy, The First Hospital of Hunan University of Chinese Medicine, Changsha 410208, Hunan \\ Province, China
}

*For correspondence: Email: yangquanwei17004@163.com; Tel: +86 18571710475

Sent for review: 15 July 2019

Revised accepted: 25 January 2020

\begin{abstract}
Purpose: To investigate the protective effect of Evodia rutaecarpa (Juss.) Benth. extract (ERBE) against Alzheimer's disease in $3 x T g-A D$ mice.

Methods: The cognitive function of $3 x T g-A D$ mice was assessed using Morris water maze test. The levels of amyloid beta deposits and NeuN in the mouse hippocampus were evaluated by immunohistochemistry. Brain neurotrophic derived factor (BDNF) and tyrosine kinase $B$ (TrkB) expressions were determined by western blot analysis.

Results: ERBE treatment significantly ameliorated learning and memory deficits in $A D$ mice, as shown by increased time spent in the target zone during probe tests. The escape latency in the animals treated with $400 \mathrm{mg} / \mathrm{kg}$ ERBE (20.5 $\pm 1.3 \mathrm{~s})$ was significantly higher than untreated $3 x T g-A D$ mice $(12.4 \pm 1.3 \mathrm{~s}$, $p<0.01)$. In addition, ERBE significantly decreased $A \beta$ deposits, increased NeuN-positive cells, and upregulated the expressions of BDNF $(1.4 \pm 0.2, p<0.05)$ and TrkB $(1.1 \pm 0.2, p<0.05)$ in $3 x \operatorname{Tg} A D$ mice.

Conclusion: The results suggest that ERBE administration may be a useful strategy for treating memory impairment induced by several neurodegenerative diseases.
\end{abstract}

Keywords: Evodia rutaecarpa, Alzheimer, Memory impairment, NeuN-positive cells

\begin{abstract}
This is an Open Access article that uses a fund-ing model which does not charge readers or their institutions for access and distributed under the terms of the Creative Commons Attribution License (http://creativecommons.org/licenses/by/4.0) and the Budapest Open Access Initiative (http://www.budapestopenaccessinitiative.org/read), which permit unrestricted use, distribution, and reproduction in any medium, provided the original work is properly credited.

Tropical Journal of Pharmaceutical Research is indexed by Science Citation Index (SciSearch), Scopus, International Pharmaceutical Abstract, Chemical Abstracts, Embase, Index Copernicus, EBSCO, African Index Medicus, JournalSeek, Journal Citation Reports/Science Edition, Directory of Open Access Journals (DOAJ), African Journal Online, Bioline International, Open-J-Gate and Pharmacy Abstracts
\end{abstract}

\section{INTRODUCTION}

Alzheimer's disease (AD) is the most common form of dementia in the elderly and accounts for between 50 and $75 \%$ of all cases. By 2030 it is estimated that more than 65 million people will be living with dementia, with projections almost doubling every 20 years. Alzheimer's disease is a progressive neurodegenerative disorder characterized, at least in part, by abnormal accumulation of $\beta$-amyloid peptide $(A \beta)$ in the brain [1]. The accumulated $A \beta$ is believed to play an important role in the pathogenesis of AD [2]. Thus, $A \beta$ continues to be an important target for prevention and treatment of $A D$ [3].

Alzheimer's disease is the most common form of dementia relating to memory and cognitive decline. Alzheimer's disease is a progressive neurodegenerative disease in which dementia 
symptoms gradually worsen over a number of years [4]. The classical biochemical hallmarks of $A D$ include the accumulation of amyloid beta $(A \beta)$ peptide oligomers and soluble hyperphosphorylated tau [5]. Brain-derived neurotrophic factor (BDNF) is a small dimeric protein, which acts through high affinity binding with its receptor, tyrosine kinase $B$ (TrkB). Brainderived neurotrophic factor (BDNF) modulates neuronal growth and survival, and BDNF is implicated in learning and memory processes; therefore, dysfunction in BDNF is accompanied by cognitive deficits. In particular, BDNF is involved in the AD-related decline in neurogenesis, and levels of nerve growth factor are also diminished with $A D$ [6].

Medical treatment for $A D$ patients is placing an increasing burden on physicians and families every year. Clinically, there are a variety of drugs available for $A D$, such as cholinesterase inhibitors, glutamate receptor antagonists, and free radical scavengers. However, these drugs do not closely target the pathogenesis of the disease and have numerous side effects [7]. Therefore, it is extremely important to elucidate the mechanism of $A D$ pathophysiology to find a new drug for treatment.

Evodia rutaecarpa (Juss.) Benth., has been used in China in the treatment of various disorders, including stress-induced physiological changes, inflammation, hypertension, and cancer. Evodia rutaecarpa (Juss.) Benth. extract has been reported to have anti-oxidant [8], immunomodulatory [9], and anti-mutagenic activities [10]. In this study, we investigated to evaluate the neuroprotective effects of ERBE on learning and memory deficits in a tripletransgenic mouse model of Alzheimer's disease (3xTg-AD), which expresses $A P P_{\text {swe }}, P S 1_{M 146 V}$, and taup301L [11].

\section{EXPERIMENTAL}

\section{Plant material}

The plant material, Evodia rutaecarpa (Juss.) Benth were collected from Changde City, Hunan Province in China in October 2018. Taxonomic identification of the plant was performed by Professor Lei Fu of Wuhan University, China. A voucher specimen (no. ERBE 201803007) was deposited in College of Pharmacy, Wuhan University, China for future reference.

The herbal samples Evodia rutaecarpa (Juss.) Benth. was dried in an oven. The abstract ERBE was obtained by steeping the dried Evodia rutaecarpa (Juss.) Benth. in water at $60{ }^{\circ} \mathrm{C}$ three times, each for one hour before first drying in an oven and then freeze-drying the ERBE thus obtained. The powder $(1 \mathrm{~g})$ was equivalent to about $1.7 \mathrm{~g}$ crude samples and the yield was $56.34 \%$.

\section{Animals}

Alzheimer's disease (3xTg-AD) mice carrying a mutant APP (KM670/671NL), a human mutant PS1 (M146V) knock-in, and tau (P301L) transgenes (B6; 129-Psen $1^{\mathrm{tm} 1 \mathrm{Mpm}} \mathrm{Tg}$ (APPSwe, tauP301L) $1 \mathrm{Lfa} / \mathrm{J}$ ) were purchased from the Animal Research Institute, Nanjing University (Nanjing, China). The non-transgenic littermates were used as wild type (WT) controls. All animals were kept in a pathogen-free environment on a $12 \mathrm{~h}$ light/12 $\mathrm{h}$ dark cycle and had access to feed and water ad libitum.

\section{Animal groups}

The mice were randomly divided into four groups ( $n=8$ ) as follows: (1) saline treated WT group (WT, $\mathrm{n}=8)$; (2) saline-treated $3 \times \mathrm{Tg}$ group (3xTg, $\mathrm{n}=8$ ); (3) $200 \mathrm{mg} / \mathrm{kg}$ ERBE-treated 3xTg group $(3 x T g p+E R B E 200, n=8)$ and (4) $400 \mathrm{mg} / \mathrm{kg}$ ERBE-treated 3xTg group (3xTgp + ERBE 400, n $=8$ ). Starting at 3 months of age, mice received PBS and ERBE once a week for 3 months until they were 6 months old. Drugs were dissolved in water, and administered using a 5-ml syringe with a 2-cm long gavage needle through the mouth to the mouth once daily for 3 weeks. The animal experiment was approved by the Animal Care and Use Committee of Wuhan University (approval ref no. 20100405) and was carried out in compliance with the Directive 2010/63/EU on the handling of animals used for scientific purposes [12].

\section{Water maze test}

A modified version of the water maze procedure described by Morris was used to test each mouse's cognitive function [13]. The water maze was a circular pool $0.9 \mathrm{~m}$ in diameter and constructed fiberglass. Water in the pool was maintained at $22 \pm 2{ }^{\circ} \mathrm{C}$ and mixed with $1 \mathrm{~kg}$ of powdered skim milk to make the water opaque. During testing in the water maze, a platform (6 $\mathrm{cm}$ in diameter) was fixed $1 \mathrm{~cm}$ below the surface of the water at identical location within the pool. The pool was surrounded by differing extra-maze cues. All mice were subjected to four trials per day at intervals of $15 \mathrm{~min}$ for four consecutive days. The proportion of time spent searching for the platform in the training quadrant, i.e, the previous location of the 
platform, was used as a measure of memory retention.

\section{Western blotting}

At the end of the experiment, the mice were decapitated and the brains were rapidly removed and placed on ice. The hippocampus was quickly dissected by a scalpel and stored at $-80^{\circ} \mathrm{C}$ fridge until use. The hippocampal tissue was homogenized in PRO-PREPTM Protein Extraction Solution (Shanghai Shengong, Shanghai, China). The homogenate was subsequently centrifuged at $12,000 \mathrm{~g}$ for $10 \mathrm{~min}$ at $4{ }^{\circ} \mathrm{C}$, and the supernatant was collected for protein concentration determination using a protein assay (Bio-Rad, Hercules, CA, USA). Protein samples $(30 \mu \mathrm{g})$ were separated on a sodium dodecyl sulfate-polyacryl-amide gel and transferred onto a nitrocellulose membrane.

The membrane was incubated with $5 \%$ skim milk in Tris-buffered saline containing $0.1 \%$ Tween-20 and then incubated overnight at $4{ }^{\circ} \mathrm{C}$ with the following primary antibodies: mouse $\beta$ actin antibody (1 : 1000; Santa Cruz Biotechnology, Santa Cruz, CA, USA), rabbit BDNF antibody (1: 500; Santa Cruz Biotechnology), and rabbit TrkB antibody (1 : 1000; Santa Cruz Biotechnology). Subsequently, membranes were incubated for $1 \mathrm{~h}$ with secondary antibodies (1:2000; Cell Signaling), and detection was performed using the enhanced chemiluminescence (ECL) detection kit.

\section{Densitometry analysis}

Coronal sections of the hippocampus were examined from the rostral anteroposterior (- 2.1 $\mathrm{mm})$ to the anteroposterior $(-4.5 \mathrm{~mm})$ direction, as defined by the bregma of the brain atlas. Images were obtained at $\times 10$ magnification using the IMAGE PRO PLUS System (version 4.0; Media Cybernetics, Silver Spring, MD, USA) on a computer attached to a light microscope (Zeiss Axioskop, Oberkochen, Germany), which interfaced with a charge-coupled device video camera (Kodak Mega Plus model 1.4 I). To determine the density of the $A \beta$-immunoreactive staining in the hippocampus, a square frame of $500 \times 500 \mu \mathrm{m}^{2}$ was placed in the dorsal part of the hippocampus. A second square frame of 200 $\times 200 \mu \mathrm{m}^{2}$ was placed in the corpus callosum to measure the background. As previously described, variations in background illumination were controlled by subtracting the average background density of the corpus callosum from the average density of the hippocampus in each section analyzed [14].

\section{Statistical analysis}

Data are presented as mean \pm standard deviation (SD). The results were analyzed statistically with one-way ANOVA followed by Tukey's multiple comparison using SPSS 16.0 software for Windows. Differences were considered statistically significant at $p<0.05$.

\section{RESULTS}

\section{ERBE reverse spatial learning deficits in 3xTgAD mice}

To examine spatial memory, the performance of animals in the probe trial was compared to the time animals spent swimming to the platform. All animals were examined by a retention test that involved removing the platform from the pool on the fourth trial day. From Table 1, the escape latency in animals treated with $400 \mathrm{mg} / \mathrm{kg}$ ERBE was significantly increased when compared to the $3 \times T g-A D$ mice.

3xTg-AD mice displayed severely impaired spatial cognition in the water maze test, when compared with the WT controls, and the administration of ERBE ameliorated these learning and memory deficits.

Table 1: Effect of ERBE on behavior in a Morris water maze $(n=6)$

\begin{tabular}{lc}
\hline Group & Escape latency (s) \\
\hline Control & $23.6 \pm 1.6$ \\
3xTg & $12.4 \pm 1.3^{* *}$ \\
ERBE-L & $13.9 \pm 0.9$ \\
ERBE-H & $20.5 \pm 1.3^{\# \#}$ \\
\hline
\end{tabular}

Escape latency was determined using the hidden platform test. Significance was determined by Student's t test $\left({ }^{* *} p<0.01\right.$, compared with the control group; ${ }^{\#} p<0.01$, compared with the $3 \times \mathrm{Tg}$ group)

\section{Effect of ERBE on $A \beta$ pathology in 3xTg-AD mice}

In $3 x \operatorname{Tg}-A D$ mice, $A \beta$ is present in the hippocampus at 6 months of age. Therefore, to investigate the link between neurogenesis and the development of $A D$ pathology, we assessed the $A \beta$ burden in brains from 3xTg-AD mice that began receiving ERBE treatments 3 month prior to 6 months of age. A $\beta$ deposits in the CA1 region of the hippocampus were significantly increased in 6-month-old 3xTg animals compared to the age-matched WT group ( $p<$ $0.01)$. In the CA3 region of the hippocampus, $A \beta$ deposits were significantly increased in the 3xTg group $(p<0.001)$ compared to the WT group ( $p$ $<0.01)$. Compared with the $3 \times \mathrm{Tg}$ group, $A \beta$ 
deposits in the CA1 region were significantly decreased by ERBE of $400 \mathrm{mg}$ treatment ( $p<$ 0.05). In addition, compared with the $3 \times \mathrm{Tg}$ group, $A \beta$ deposition in the CA3 was significantly decreased by ERBE $200 \mathrm{mg}$ treatment $(p<$ 0.05). However, there were no significant differences between the 3xTg group and the $3 x$ Tgp ERBE $(400 \mathrm{mg} / \mathrm{kg})$ groups (Table 2$)$.

Table 2: Effect of ERBE on the deposition of $A \beta$ in the hippocampus $(n=6)$

\begin{tabular}{lcc}
\hline Group & $\begin{array}{c}\text { Amyloid beta } \\
\text { deposits in CA1 } \\
\text { (\% of } \mathbf{3 x T g} \text { ) }\end{array}$ & $\begin{array}{c}\text { Amyloid beta } \\
\text { deposits in CA3 } \\
\text { (\% of } \mathbf{3 x T g} \text { ) }\end{array}$ \\
\hline control & $51.5 \pm 2.2$ & $71.7 \pm 1.5$ \\
$3 \times T g$ & $103.7 \pm 3.4^{* *}$ & $102.8 \pm 2.3^{* *}$ \\
ERBE-L & $92.3 \pm 2.5$ & $89.2 \pm 2.1$ \\
ERBE-H & $75.8 \pm 2.1^{\#}$ & $77.4 \pm 1.7^{\#}$ \\
\hline Data are shown as mean \pm SEM; ${ }^{* *} p<0.01$, when \\
compared with control mice; ${ }^{\#} p<0.05$ compared with \\
3xTg group (one-way ANOVA and Tukey's post-hoc \\
tests) \\
\multicolumn{3}{l}{ Effect of ERBE on expressions of BDNF and } \\
TrkB and in mouse hippocampus
\end{tabular}

The results are shown in Table 3. The expression of hippocampal BDNF and rkB of $3 x T g$ mice treatment with saline was significantly lower compared with that of WT mice $(p<0.05)$. It was also demonstrated that ERBE treatment significantly increased the expression of hippocampal BDNF and TrkB. These results show that the induction of $A D$ reduced $B D N F$ and TrkB expressions in the hippocampus, whereas, ERBE treatment enhanced BDNF and TrkB expressions in the hippocampus of the $3 \times \mathrm{Tg}$ mice.

Table 3: Effect of ERBE on BDNF and TrkB expressions in the hippocampus

\begin{tabular}{ccc}
\hline Group & $\begin{array}{c}\text { TrkB/beta } \\
\text { action ratio }\end{array}$ & $\begin{array}{c}\text { BDNF/beta action } \\
\text { ratio }\end{array}$ \\
\hline Control & $1.3 \pm 0.3$ & $1.2 \pm 0.3$ \\
$3 \times T g$ & $0.7 \pm 0.1^{*}$ & $0.8 \pm 0.2^{*}$ \\
ERBE-L & $0.9 \pm 0.3$ & $0.9 \pm 0.2$ \\
ERBE-H & $1.1 \pm 0.2^{\#}$ & $1.4 \pm 0.2^{\#}$ \\
\hline Asterisk indicate significant difference at ${ }^{*} p<0.05$, \\
compared to control mice; ${ }^{\#} p<0.05$, compared to \\
3xTg mice (one-way ANOVA and Tukey's post-hoc \\
tests)
\end{tabular}

\section{DISCUSSION}

The present study demonstrated that ERBE increased spatial learning, memory abilities, and the expression of hippocampal BDNF and TrkB in 3xTg-AD mice. In this study, we chose to use the 3xTg-AD mice, a model derived from APPS $w e, P S 1_{M 146 V}$, and taup301L transgenes. The
3xTg-AD mice develop a progressive, agerelated neuropathological phenotype that includes plaque and tangle pathologies. These hallmark lesions are limited mainly to the hippocampus, amygdala, and cerebral cortex the brain structures most impacted by $A D$ pathology [15].

Cognitive impairment has been detected in 2month-old 3xTg-AD mice [16], and $A \beta$ deposits in the hippocampus and cortex have been found in 6-month-old 3xTg-AD mice [17-19]. These findings indicate that the pathological features that imitate $A D$ in $3 x \operatorname{TgAD}$ mice remain stable. Classic symptoms of $A D$ include problems with spatial learning and memory deficits. This study demonstrated that treatment with ERBE resulted in a significant restoration of spatial learning and memory function in $A D$ mice. These results suggest that ERBE treatment may be effective in ameliorating cognitive impairment caused by $A D$.

Neuron-specific nuclear antigen (NeuN) is a neuronal-specific nuclear protein [20,21]. The expression of NeuN is observed in most neuronal cell types throughout the nervous system, with the exception of some neuronal populations that are NeuN-negative, but does not stain nonneuronal cells [22]. NeuN is a soluble nuclear protein that is localized to the cell nucleus and in the neuronal cytoplasm of postmitotic neurons. Within the hippocampus, NeuN can be used as a marker of postmitotic cells and labels both "normal" post-mitotic neurons and newly generated post-mitotic neurons. BDNF plays pivotal roles in learning, memory, and neuronal plasticity.

The levels of BDNF, and its main receptor TrkB, have been reported to lessen in $A D$. It was hypothesized that BDNF and its receptor may be involved in the protective role of ERBE against memory impairment.

The results of the present study have demonstrated that ERBE intake significantly increases the expression of BDNF and its main receptor TrkB, in the brain, which is in agreement with the hypothesis. There is evidence to support the results. It has been demonstrated that BDNF and TrkB are capable of protecting against memory impairment and regulate neurogenesis in the hippocampus of AD. A recent study also supports the role of BDNF signaling through TrkB in the pathophysiology and cognitive and its receptor involving ERBE in $A D$ [23]. 


\section{CONCLUSION}

The findings of this study reveal that ERBE attenuates learning and memory deficits in 3xTg$A D$ mice. Thus, the herbal extract can potentially be developed as an alternative therapeutic agent for the management of $A D$.

\section{DECLARATIONS}

\section{Conflict of interest}

No conflict of interest is associated with this work.

\section{Contribution of authors}

We declare that this work was done by the authors named in this article and all liabilities pertaining to claims relating to the content of this article will be borne by the authors. Ang Cai and Liu Xiao equally contributed to this work, and they are co-first authors.

\section{Open Access}

This is an Open Access article that uses a funding model which does not charge readers or their institutions for access and distributed under the terms of the Creative Commons Attribution License (http://creativecommons.org/licenses/by/ 4.0) and the Budapest Open Access Initiative (http://www.budapestopenaccessinitiative.org/rea d), which permit unrestricted use, distribution, and reproduction in any medium, provided the original work is properly credited.

\section{REFERENCES}

1. Billings $L M$, Oddo $S$, Green $K N$, McGaugh JL, LaFerla FM. Intraneuronal Abeta causes the onset of early Alzheimer's disease-related cognitive deficits in transgenic mice. Neuron 2005; 45: 675-688.

2. Chadwick W, Mitchell N, Caroll J, Zhou Y, Park SS. Amitriptyline-mediated cognitive enhancement in aged $3 x T g$ Alzheimer's disease mice is associated with neurogenesis and neurotrophic activity. PLOS One 2011; 6: 21660-21662.

3. Chen W, Cheng X, Chen J, Yi X. Lycium barbarum polysaccharides prevent memory and neurogenesis impairments in scopolamine-treated rats. PLOS One 2014; 9: 88076-88078.

4. Chung YC, Kim SR, Park JY. Fluoxetine prevents MPTPinduced loss of dopaminergic neurons by inhibiting microglial activation. Neuropharmacol 2011; 60: 963974.

5. Geloso MC, Corvino V, Cavallo V, Toesca A, Guadagni E, Passalacqua R, Michetti F. Expression of astrocytic nestin in the rat hippocampus during trimethyltininduced neurodegeneration. Neurosci Lett 357; 103106.

6. Geloso MC, Vercelli A, Corvino V, Repici M, Boca M, Haglid K, Zelano G, Michetti F. Cyclooxygenase-2 and caspase 3 expression in trimethyltin-induced apoptosis in the mouse hippocampus. Exp Neurol 2002; 175: 152 160.

7. Herculano-Houzel S, Lent $R$. Isotropic fractionator: a simple, rapid method for the quantification of total cell and neuron numbers in the brain. J Neurosci 2005; 25: 2518-2521.

8. Hsiao YH, Hung HC, Chen SH, Gean PW. Social interaction rescues memory deficit in an animal model of Alzheimer's disease by increasing BDNF-dependent hippocampal neurogenesis. J Neurosci 2014; 34: 16207-16219.

9. Hubka P. Neural network plasticity, BDNF and behavioral interventions in Alzheimer's disease. Bratisl Lek Listy 2006; 107: 395-401.

10. Li XY, Guo F, Zhang QM, Huo TT, Liu LX, Wei HD, Xiong LZ, Wang Q. Electroacupuncture decreases cognitive impairment and promotes neurogenesis in the APP/PS1 transgenic mice. BMC Complement. Altern Med 2014; 14: 37-39.

11. Lind D, Franken S, Kappler J, Jankowski J, Schilling K. Characterization of the neuronal marker NeuN as a multiply phosphorylated antigen with discrete subcellular localization. J Neurosci Res 2005; 79: 295-302.

12. European Commission [homepage on the internet]. Directive 2010/63/EU on the protection of animals used for scientific purposes [cited 2013 Jan 16]. Available from: $h$ ttp://ec.europa.eu/environment/chemicals/lab_ animals/legislation_en..htm.

13. Morris R. Developments of a water-maze procedure for studying spatial learning in the rat. J. Neurosci. Methods 1984; 11: 47-60.

14. Mullen RJ, Buck CR, Smith AM. Neu N. a neuronal specific nuclear protein in vertebrates. Development 1992; 116: 201-211.

15. Nagahara AH, Merrill DA, Coppola G, Tsukada S, Schroeder BE, Shaked GM, Wang L, Blesch A. Neuroprotective effects of brain-derived neurotrophic factor in rodent and primate models of Alzheimer's disease. Nat Med 2009; 15: 331-337.

16. Oddo S, Caccamo A, Shepherd JD, Murphy MP, Golde $T E$, Kayed R, Metherate R, Mattson MP, Akbari $Y$, LaFerla FM. Triple-transgenic model of Alzheimer's disease with plaques and tangles: intracellular Abeta and synaptic dysfunction. Neuron 2003; 39: 409-421.

17. Oddo S, Caccamo A., Tran L, Lambert MP, Glabe CG, Klein WL, LaFerla FM. Temporal profile of amyloid-beta (Abeta) oligomerization in an in vivo model of Alzheimer disease. A link between Abeta and tau pathology. J Biol Chem 2006; 281: 1599-1604.

18. Park HJ, Shim HS, Choi WK, Kim KS, Bae H, Shim I. Neuroprotective effect of Lucium chinense fruit on 
trimethyltin-induced learning and memory deficits in the rats. Exp Neurobiol 2011; 20: 137-143.

19. Ritter JM. Drugs for Alzheimer's disease. $\mathrm{Br} J$ Clin Pharmacol 2012; 73: 501-503.

20. Selkoe DJ. Images in neuroscience. Alzheimer's disease: from genes to pathogenesis. Am J Psychiat 1997; 154: 1198-1201.

21. Xiao Y, Harry GJ, Pennypacker KR. Expression of AP-1 transcription factors in rat hippocampus and cerebellum after trimethyltin neurotoxicity. Neurotoxicol 1999; 20: 761-766.
22. Ye M, Lee SG, Chung ES, Lim SJ. Neuroprotective effects of cuscutae semen in a mouse model of Parkinson's disease. Evid Based Complem Altern Med 2014; 2014: 150153-150155.

23. Yu MS, Leung SK, Lai, SW, Che CM, Zee SY, So KF, Yuen WH, Chang RC. Neuroprotective effects of antiaging oriental medicine Lycium barbarum against betaamyloid peptide neurotoxicity. Exp Gerontol 2005; 40: 716-727. 